\title{
Pengembangan Model Pembelajaran Dakonan Jodoh (DAJ0) Pada Pembelajaran Tematik Di Sekolah Dasar
}

\author{
Nita Pratiwi1 ${ }^{*}$, Fajar Cahyadi², M. Yusuf Setia Wardana ${ }^{3}$ \\ 123 Jurusan PGSD, FIP Universitas PGRI Semarang Semarang, Indonesia
}

\begin{abstract}
Abstrak
Pembelajaran tematik pada dasarnya membutuhkan optimalisasi penggunaan model dan media pembelajaran yang bervariasi sehingga akan membantu siswa dalam memahami konsep - konsep materi yang bersifat abstrak. Maka dari itu penggunaan model pembelajaran berbantuan media pembelajaran merupakan hal yang penting dalam sebuah pembelajaran. Guru dituntut untuk kreatif dan produktif dalam membuat dan menggunakan media pembelajaran. Indonesia merupakan salah satu negara dengan berbagai macam kebudayaan tradisional. Salah satu bentuk kebudayaan tersebut adalah pemainan tradisional dan setiap daerah provinsi di Indonesia memiliki permainan tradisional. Untuk menyediakan variasi model pembelajaran dan melestarikan kebudayaan daerah diperlukan sebuah model pembelajaran yang dikombinasikan dengan media pembelajaran permainan tradisional yaitu permainan dakon.
\end{abstract}

\section{Keywords:}

Pembelajaran tematik, model pembelajaran, permainan dakon

\section{PENDAHULUAN}

Pendidikan merupakan program pemerintah yang wajib didapatkan oleh semua generasi penerus bangsa. Melalui pendidikan, generasi penerus bangsa memiliki sikap, moral, dan karakter yang baik. Sikap, moral, dan karakter dapat dikembangkan melalui implementasi kurikulum dalam pendidikan. Menurut Habibi (2017) menyatakan bahwa Pelaksanaan pembelajaran tematik merupakan implementasi dari kurikulum yang berlaku Pelaksanaan kurikulum 2013 pada tahun 2018 sejalan dengan program pemerintah nawacita yaitu penguatan pendidikan karakter. Pendidikan karakter kini memang menjadi isu utama pendidikan sejak tahun 2010. Selain menjadi bagian dari proses pembentukan ahlak anak bangsa, pendidikan karakter ini pudiharapkan mampu menjadi pondasi utama dalam meningkatkan derajat dan maratabat bangsa Indonesia (Dewi, 2014).

Teori belajar yang melandasi pembelajaran tematik integratif. Penerapan model tematik integratif. Permendiknas Nomor 22 Tahun 2008 secara tegas mengatakan pembelajaran paa Kelas I s.d. III dilaksanakan melalui pendekatan Tematik Integratif, sedangkan pada kelas IV s.d. VI dilaksanakan melalui pendekatan mata pelajaran. Penerapan untuk kelas rendah (1,2, dan 3) Sekolah Dasar dilakukan dengan pendekatan tematik integratif jarring laba-laba. Kelas atas (4,5, dan 6) dengan pendekatan integratif atau terpadu beberapa mata pelajaran dalam (Ahmadi \& Amri, 2014 : 98-99)

Landasan teoritis penggunaan media pendidikan. Pemerolehan pengetahuan dan ketrampilan, perubahan-perubahan sikap dan perilaku dapat terjadi karena interaksi antara pengalaman baru dengan pengalaman yang pernah dialami sebelumnya. Menurut Bruner (1966: 10-11) ada tiga tingkatan utama modus belajar, yaitu pengalaman lagsung

Dalam (Suyadi, 2013: 8-9) mengatakan "nilai karakter cinta tanah air dapat diajarkan pada siswa melalui sikap dan perilaku yang mencerminkan rasa bangga dan peduli dengan budaya bangsa". Misalnya 
adalah melestarikan permainan tradisional yang dimiliki Indonesia yakni salah satunya permainan tradisional dakonan. Permainan tradisional Dakonan tumbuh dan berkembang pada masyarakat Jawa.

Sudjana \& Rivai dalam (Arsyad, 2011: 24) menjelaskan bahwa "manfaat media pembelajaran dalam proses belajar siswa adalah pembelajaran dapat lebih menarik perhatian siswa. Proses pembelajaran akan lebih mudah dipahami jika seorang guru menggunakan alat atau media untuk mencapai suatu tujuan tersebut".

Berdasarkan hasil observasi yang dilakukan di SD Negeri 01 Sengon Bugel dan SD Negeri 02 Jebol, Kecamatan Mayong Kabupaten Jepara. Saat observasi, angket diberikan untuk diisi sesuai dengan keadaan yang sesungguhnnya kepada guru dan siswa kelas IV Sekolah Dasar serta mengamati proses pembelajaran di kelas IV SD Negeri 01 Sengon Bugel dan SD Negeri 02 Jebol. Hasil angket mengenai masalah dan kebutuhan guru. Berdasarkan kendala yang dialami oleh guru sebanyak 13 guru, sebesar $30 \%$ menjawab keterbatasan buku dan keterlambatan buku serta penilaian raport yang rumit, sebesar 23\% menjawab kurangnya keefektifan waktu mengajar, sebesar $15 \%$ menjawab sulit untuk menjelaskan menggunakan kurikulum 2013 dan sebesar 30\% menjawab proses pembelajaran yang masih belum menggunakan model dan media pembelajaran yang bervariasi sehingga siswa mudah merasa bosen dengan proses pembelajaran yang dilakukan guru serta siswa terkesan kurang menyenangkan dari sebanyak 13 guru. Untuk angket kebutuhan guru didapatkan hasil sebagai berikut, sebesar 53\% guru menjawab pernah menggunakan model pembelajaran make a match dan sebesar $46 \%$ guru menjawab tidak pernah, sebesar $38 \%$ guru menjawab pernah menggunaka permainan tradisional dakonan dalam pembelajaran dan $61 \%$ guru menjawab tidak pernah, sebesar $100 \%$ guru menjawab memerlukam model pembelajaran make a match yang dikombinasikan dengan permainan tradisional dakonan dan sebesar 84\% guru menjawab tertarik menggunakan model pembelajaran make a match yang dikombinasikan dengan permainan tradisional dakonan dan $15 \%$ guru menjawab tidak tertarik. Kemudian untuk angket kebutuhan siswa rinciannya sebagai berikut, dari keseluruhan jumlah angket yang diberikan yakni 20 angket, sebesar $5 \%$ siswa menjawab guru menggunakan media dalam pembelajaran, sebesar $65 \%$ siswa menjawab guru tidak menggunakan media dalam pembelajaran dan sebesar $30 \%$ siswa menjawab guru jarang menggunakan media dalam pembelajaran. Sebesar $40 \%$ siswa menjawab bahwa guru pernah melakukan pembelajaran menggunakan model pembelajaran make a match yang di padukan dengan permainan tradisional dan sebesar $60 \%$ siswa menjawab bahwa guru tidak pernah melakukan pembelajaran menggunakan model pembelajaran make a match yang di padukan dengan permainan tradisional. Sebesar $60 \%$ siswa menjawab bahwa pembelajaran yang menggunakan media pembelajaran akan lebih menyenangkan dan sebesar $40 \%$ siswa menjawab bahwa pembelajaran yang tidak menggunakan media pembelajaran akan lebih menyenangkan. Sebesar $10 \%$ siswa menjawab pernah menggunakan permainan tradisional dalam pembelajaran dan sebesar $90 \%$ siswa menjawab tidak pernah menggunakan permainan tradisional dalam pembelajaran. Sebesar $45 \%$ siswa menginginkan media gambar dalam pembelajaran, sebesar $50 \%$ siswa menginginkan menggunakan permainan tradisional dalam pembelajaran dan sebesar $5 \%$ menggunakan media elektonik, menari dalam pembelajaran. Untuk dapat mengatasi persoalan tersebut, proses penyampaian materi tematik dapat ditunjang dengan menggunakan model dan media pembelajaran yang menarik dan menyenangkan.

Sehingga salah satu contoh media yang dapat digunakan yakni dengan menggunakan model pembelajaran Dakonan Jodoh (DAJO). Selain untuk media pembelajaran, media permainan tradisional dakonan juga bisa memperkanalkan dan mengajarkan tentang kebudayaan Indonesia. Dengan perkembangan zaman, permainan tradisional dakonan semakin tergeser dengan permainan game game online yang lebih menarik bagi anak, maka dari itu penulis akan mengemas pembelajaran tematik dengan menggunakan model pembelajaran Dakonan Jodoh (DAJO) agar pembelajaran dapat bersifat PAIKEM (pembelajaran aktif, inovatif, kreatif, efektif, menyenangkan).

\section{METODE PENELITIAN}

Penulis dalam penelitian ini menggunakan metode Research and Development(R\&D) yaitu sebuah proses atau langkah-langkah dalam rangka mengembangkan suatu produk baru atau menyempurnakan produk yang sudah ada. "Metode penelitian dan pengembangan adalah metode penelitian yang digunakan untuk menghasilkan prosuk tertentu dan menguji keefektifan prosuk tersebut" (Sugiyono, 2015: 407).

Dari studi lapangan dalam penelitian dan pengembangan yang digunaakn adalah SD Negeri 01 Sengon Bugel dan SD Negeri 02 Jebol. Dari studi lapangan di SD Negeroi 01 Sengon Bugel dan SD Negeri 02 Jebol, penulis menemukan masalah yakni Keefektifan waktu mengajar, sulit menjelaskan kepada siswa menggunakan kurikulum 2013, media pembelajaran yang kurang mendukung, guru membutuhkan sebuah model pembelajaran yang menarik, guru menginginkan media pembelajaran yang menarik, siswa membutuhkan model dan media pembelajaran yang dikombinasikan dengan permainan tradisional 
Untuk menyikapi masalah-masalah yang ada di kedua kelas tersebut dengan menggembangkan sebuah produk pembelajaran yang berupa model pembelajaran Dakonan Jodoh (DAJO) pada pembelajaran tematik sekoalah dasar. Produk yang dihasilkan dalam penelitian ini adalah model pembelajaran Dakonan Jodoh (DAJO)

Langkah yang dialakukan penulis pada tahap ini adalah sebagai berikut : (a) melakukan tinjuaan terhadap materi pembelajaran yang akan berpedoman pada Kompetensi Inti, Kompetensi Dasar, dan Indikator, membaca sumber yang berkaitan dengan pembelajran tematik. (b) mengkaji materi sebagai dasar dalam memilih bentuk dan desain media.

Desain Produk dalam penelitian ini yaitu: (a) Menyusun kisi-kisi dan membuat instrument penilaian untuk menilai kualitas media, (b) Melakukan validasi instrument kepada dosen pembimbing dan guru kelas, (c) Membuat Prorotipe media permaian tradisional dakonan. Langkah pertama, penulis menghias media dakonan agar lebih menarik, langkah kedua membuat kartu pertanyaan-jawaban yang didesain dengan desain yang sesuai dengan karakteristik anak SD, (d) Melakukan validasi media kepada ahli media dan ahli mataeri untuk mengetahui tingkat kelayakan media dan model dengan materi dalam pembelajaran, (e) Menyusun sintaks penggunaan media permainan tradisional dakonan, (f) Menyusun RPP, (g) Konsultasi dengan dosen pembimbing 1 dan 2

Penulis melakukan uji coba terbatas dengan subjek penelitian siswa kelas IV SD Negeri 01 Sengon Bugel dan SD Negeri 02 Jebol penulis menggunakan angket sebagai pengumpulan data untuk kemudian dianalisis. Dalam penelitian dan pengembangan media dan model pembelajaran ini memerlukan subjek yang akan memvalidasi hal tersebut. Subjek terdiri dari subjek penilai yaitu ahli media dan ahli materi. Ahli media 1 yaitu Sinngih Adi Prasetyo, M.Pd dan ahli materi 2 yaitu Asep Ardiyanto, M.Pd dan Veryliana Purnamasari, M.Pd. Berdasarkan hasil uji coba terbatas dan dianalisis data maka dilakukan perbaikan model pembelajaran Dakona Jodoh (DAJO)

Sasaran subjek penelitian penerapan produk pengembangan model dan media ini adalah siswa kelas IV SD Negeri 01 Sengon Bugel dan SD Negeri 02 Jebol yang berada di kecamatan Mayong kabupaten Jepara. Instrumen yang digunakan dalam penelitian adalah : (a) Angket analisis kebutuhan siswa: Lembar angket analisis kebutuhan siswa digunakan dalam proses studi pendahuluan. Lembar angkat ini diberikan kepada siswa untuk mengetahui bagaimana tanggapan siswa terhadap proses pembelajaran tematik yang selama ini dilakukan oleh guru, bagaimana penggunaan media yang digunakan oleh giru dalam proses pembelajaran. (b) Angket analisis kebutuhan dan masalah guru: Lembar angket analisis kebutuhan guru digunakan dalam proses studi pendahuluan. Lembar angket ini diberikan kepada guru untuk mengetahui bagaimana proses pembelajaran yang selama ini guru lakukan di sekolah untuk mengetahui pendapat guru mengenai media permainan tradisional dakonan. (c) Angket respon siswa: Lembar angket peserta didik digunakan untuk mengatasi kelayakan penggunaan media pembelajaran yang dikembangkan. (d) Angket respon guru: Lembar angket peserta didik digunakan untuk mengatasi kelayakan penggunaan media pembelajaran yang dikembangkan.

Pada tahap revisi produk, akan dilakukan evaluasi. Evaluasi dilakukan untuk meninjau apakah produk layak digunakan atau tidak. Evaluasi meliputi perbaikan produk yang diperoleh dari saran pada angket yang sudah diberikan pada uji ahli media dan uji ahli materi yang selanjutnnya dapat gunakan untuk perbaikan. Teknik pengumpulan data dalam penelitian ini yaitu dengan teknik wawancara, observasi, dokumentasi. Sementara analisis data dilakukan untuk melihat nilai masing-masing aspek pada angket. Data diperoleh dari angket yang diberikan kepada ahli media, ahli materi, dan siswa. Data yang terkumpul dianalisis dengan cara menghitung rata-rata skor yang diperoleh.

\section{ANALISIS DAN PEMBAHASAN}

Model pembelajaran dakonan jodoh dikembangkan oleh peneliti berdasarkan langkah-langkah penelitian dan pengembangan (research and development). Peneliti menggunakan desain pemengembangan yang dikemukakan oleh Borg and Gall. Produk pada penelitian ini merupakan suatu karya model pemebelajaran dakonan jodoh (DAJO) yang digunakan sebagai model pembelajaran supaya siswa dapat belajar namun juga dapat bermain dengan nyata di dalam kelasa bersama teman-teman satu kelasnya. Selain itu juga pengembangan model pembelajaran dakonan jodoh (DAJO) ini dibuat supaya siswa lebih bersemangat dalam balajar.

1. Hasil Validasi Ahli Media

Tahap validasi ahli media bertujuan untuk menegtahui kelayakan pembuatan produk model pembelajaran yang didalamnya terdapat media pembelajaran berupa media dakonan, kartu soal dan jawaban sebelum dilakukan uji coba lapangan. Pada tahap ini, satu validator dipilih sebagai validator ahli media yang merupakan dosen Pendidikan Guru Sekolah Dasar Universitas PGRI Semarang Bapak Singgih 
Adhi Prasertyo, S.Sn, M.Pd. Validasi media dilakukan dengan memberikan lembar angket validasi ahli media.

Hasil analisis penilaian ahli media validasi pertama mendapatkan presentase skor yang meliputi aspek indikator kesesuaian produk model pembelajaran dakonan jodoh (DAJ0) 75\%, kelayakan produk 90\%, kontribusi produk 81,25\%, keunggulan produk 93,25\%. Sehingga hasil analisi penilaian ahli media validasi pertama mendpatkan presentase skor total sebesar 85,29\% dengan kriteria sangat layak. Setelah revisi produk, kemudian dilakukan validasi media kedua dengan presentase skor yang meliputi aspek kesesuaian model pembelajaran dakonan jodoh (DAJO) 93,75\%, aspek kelayakan produk 95\%, aspek kontribusi produk 93,25\%, aspek keunggulan produk 93,25\%. Presentase total skor pada validasi kedua sebesar 94,11 dengan kriteria sangat bai

2. Hasil Validasi Ahli Materi

Tahap validasi ahli materi pembelajaran bertujuan untuk melihat sejauh mana materi yang ada pada model pembelajaran tersebut. Pada tahap ini, dua validator dipilih sebagai validator ahli materi media yang merupakan dosen Pendidikan Guru Sekolah Dasar Universitas PGRI Semarang yaitu Bapak Asep Ardiyanto, M.Or dan Ibu Veryliana Purnamasari, S.Pd, M.Pd. Validasi model pembelajaran dilakukan dengan memberikan lembar angket validasi ahli media.

Hasil analisis penilaian ahli materi pertama pada validasi pertama mendapatkan presentase skor yang meliputi indikator kesesuaian produk 87,5\%, indokator kelayakan 87,5\%, indikator penyajian 100\%, indikator kompetensi 91,67\%. Sehingga hasil analisis penelian ahli media pada validasi pertama mendapatkan skor total sebesar $90,62 \%$ dengan kualifikasi sangat baik.

Setelah revisi produk, dilakukan validasi meteri kedua yang diperoleh hasil analisis penilaian dengan presentase skor yang meliputi indikator kesesuaian produk 93,75\%, indokator kelayakan 93,75\%, indikator penyajian 100\%, indikator kompetensi 100\%. Sehingga hasil analisis penelian ahli materi pada validasi pertama mendapatkan skor total sebesar 97,06\% dengan kualifikasi sangat baik.

Hasil analisis penilaian ahli media pada validasi pertama mendapatkan presentase skor yang meliputi indikator kesesuaian produk 75\%, indokator kelayakan 87,5\%, indikator penyajian 75\%, indikator kompetensi 79,67\%. Sehingga hasil analisis penelian ahli materi pada validasi pertama mendapatkan skor total sebesar 79,62\% dengan kualifikasi baik.

Setelah revisi produk, dilakukan validasi meteri kedua yang diperoleh hasil analisis penilaian dengan presentase skor yang meliputi indikator kesesuaian produk 93,75\%, indokator kelayakan 87,5\%, indikator penyajian $100 \%$, indikator kompetensi $87,05 \%$. Sehingga hasil analisis penelian ahli materi pada validasi pertama mendapatkan skor total sebesar $91,17 \%$ dengan kualifikasi sangat baik.

Dilihat dari tiap indikator. Hasil analisis penilian ahli materi pertama dan kedua pada validasi kedua terlihat meningkat. Hal ini sesuai dengan Asyhar (2012: 8) bahwa peran media dalam pembelajaran mengaruskan para pendidik untuk lebih kreatif dan inovatif dalam memanfaatkan sumber belajar dan media.

3. Hasil Angket Respon Guru Kelas

Hasil angket respon guru kelas bertujuan untuk mengetahui respon guru kelas terhadap kelayakan model pembelajaran pada uji coba lapangan dengan dilakukan pengisian angket respon guru kelas IV di SD Negeri 02 Jebol dan SD Negeri 01 Sengon Bugel diperoleh hasil sebagai berikut :

Hasil Angket respon guru kelas IV SD Negeri 02 Jebol (Rima Maya Sofa, S.Pd) mendapatkan skor 100\% dan SD Negeri 01 Sengon Bugel (Endang Puji Astutik, S.Pd) mendapatkan skor 82,5. Dari data diatas selanjutnya diperoleh presntase skor total hasil angket respon guru kelas sebesar 91,25\% dengan kriteria sangat layak. Hal ini karena kit model pembelajaran dakonan jodoh (DAJO) sesuai dengan materi yang dikemas menarik dan sesuai, terdapat RPP, terdapat penilaian sikap dan ketrampilan selain penilaian pengetahuan serta terdapat permainan trasdisional dakonan dalam model pembelajaran. Dengan adanya kriteria sangat layak maka model pembelajaran dakonan jodoh (DAJO) dapat digunakan sebagai model pembelajaran yang cocok untuk diterapkan di dalam pembelajaran di kelas.

4. Hasil Angket Respon Siswa

Model pembelajaran dakonan jodoh (DAJO) merupakan suatu hal baru yang diperoleh siswa. Hasil angket respon siswa bertujuan untuk mengetahui respon siswa terhadap keberterimaan model pembelajaran dakonan jodoh (DAJO) pada uji coba lapangan dengan dilakukan pengisian angket respon siswa kelas IV di SD Negeri 02 Jebol dan SD Negeri 01 Sengon Bugel dan diperoleh hasil sebagai berikut

Hasil angket respon siswa kelas IV SD Negeri 02 Jebol mendapatkan presentase skor 100\% dan SD Negeri 01 Sengon Bugel mendapatkan presentase skor 77,88\%. Dari data diatas selanjutnya diperoleh presentase total hasil angket respon siswa sebesar 88,94\% dengan kriteria sangat layak. Karena model pembelajaran sesuai dengan karakteristik anak jenjang SD yang senang bermain dalam kehidupan seharihari anak. 
Berdasarkan dari skor total angket respon siswa diatas menunjukkan proses pembelajaran dengan model pembelajaran dakonan jodoh (DAJO) dapat digunakan sebagai model pembelajaran dengan bermain secara praktis. Pengembangan model pembelajaran dakonan jodoh (DAJO) dapat menjadikan siswa dapat bermain sambil bermain dalam pembelajaran dan membuat suasana proses penyampaian materi menjadi dangat menyenangkan. Dengan demikian, siswa menjadi semangat dalam belajar. Model pembelajaran dakonan jodoh (DAJO) ini juga dapat meningkatkan aspek sikap, pengetahuan, dan ketrampilan.

Pengembangan model pembelajaran ini memiliki keunggulan dan kelemahan saat digunakan dalam pembelajaran. Keunggulan yang dimiliki adalah terletak pada sifatnya yang peralatannya mudah di dapatkan, mudah dibawa kemana-mana dengan tampilan menarik serta terdapat permainan tradisional di dalam model pembelajarannya, dapat dimainkan dalam kelas maupun diluar kelas dan tidak menyebabkan cidera ketika dilakukan sehingga aman untuk digunakan anak-anak. Selain kelebihan yang dimiliki, media ini juga memiliki kelemahan. Kelemahannya adalah model pembelajaran ini terdapat banyak langkah-langkah yang yang harus dipahami terlebih dahulu dan ketika tidak memahami terlebih dahulu langkah-langkahnya maka akan bingung menerapkannya.

\section{KESIMPULAN}

Pembelajaran tematik khususnya tematik integratif pada dasarnya membutuhkan optimalisasi penggunaan media pembelajaran yang bervariasi sehingga akan membantu siswa dalam memahami konsep - konsep materi yang bersifat abstrak. Guru dituntut kreatif untuk menggunakan model dan media selama pembelajaran. Indonesia merupakan salah satu negara dengan berbagai macam kebudayaan tradisional. Salah satu bentuk kebudayaan tersebut adalah pemainan tradisional dan setiap daerah provinsi di Indonesia memiliki permainan tradisional. Model pembelajaran DAJO hadir sebagai salah satu solusi untuk membantu guru agar pembelajaran dapat bersifat PAIKEM (pembelajaran aktif, inovatif, kreatif, efektif, menyenangkan) dan untuk melestarikan permainan tradisional.

\section{DAFTAR PUSTAKA}

Aeni, A.N., 2014. Pendidikan Karakter Untuk Siswa SD Dalam Perspektif Islam. Mimbar Sekolah Dasar, 1(1), pp.50-58.

Afandi, R., 2011. Integrasi Pendidikan Karakter dalam Pembelajaran IPS di Sekolah Dasar. PEDAGOGIA: Jurnal Pendidikan, 1(1), pp.85-98.

Amri, Ahmadi. 2014. Pengembangan \& Model Pembelajaran Tematik Integratif. Jakarta: Prestasi Pustaka

Aliputri, Dhestha Hazilla. 2018. Penerapan Model Pembelajaran Kooperatif Tipe Make A Match Berbantuan Kartu Bergambar Untuk Meningkatkan Hasil Belajar Siswa. Jurnal. Di terbitkan. Fakultas Ilmu Pendidikan Universitas Satya Wacana : Salatiga

Arsyad. 2016. Media Pembelajaran. Jakarta: PT RajaGrafindo Persada

Dewi, N.L.L.A., Putrayasa, I.B. and Nurjaya, I.G., 2014. Analisis Nilai-Nilai Pendidikan Karakter Novel Sepatu Dahlan Karya Khrisna Pabichara dan Relevansinya terhadap Pengajaran Pendidikan Karakter Sekolah di Indonesia. Jurnal Pendidikan Bahasa dan Sastra Indonesia Undiksha, 2(1).

Habibi, M., 2017. PEMBELAJARAN TEMATIK DI SEKOLAH DASAR. Insania, 17(1), pp.113-128.

Huda. 2014. Model-model Pengajaran dan Pembelajaran. Yogyakarta: Pustaka Pelajar

Judiani, S., 2010. Implementasi pendidikan karakter di sekolah dasar melalui penguatan pelaksanaan kurikulum. Jurnal pendidikan dan kebudayaan, 16(9), pp.280-289.

Mulyasa. 2013. Pengembangan dan Implementasi Kurikulum 2013. Bandung: PT. Remaja Rosdakarya

Mustadi, ali dan Arih. 2017. Permainan Dakon Bertema Untuk Meningkatkan Kemampuan Berpikir Kritis Pada Pembelajaran Tematik Integratif Siswa Kelas V SD. Jurnal. Di terbitkan. Fakultas Pendidikan Dasar Pascasarjana Universitas Negeri Yogyakarta : Yogyakarta

Nurseto, T., 2011. Membuat media pembelajaran yang menarik. Jurnal Ekonomi dan Pendidikan, 8(1). 
Rismawati. 2012. Menstimulasi Perkembangan Otak Dengan Permainan (Untuk Anak Usia 0-12 Tahun). Yogyakarta: Pedagogia

Sugiyono. 2015. Metode Penelitian Pendidikan. Bandung: Alfabeta

Suyadi. 2013. Strategi Pembelajaran Pendidikan Karakter. Bandung: PT Remaja Rosdakarya

Susanto. 2016. Teori Belajar dan Pembelajaran di Sekolah Dasar. Jakarta: Prenadamedia Group 